\title{
NOTA
}

\section{EXTRACTION AND CONCENTRATION OF BIOGENIC CALCIUM OXALATE FROM PLANT LEAVES ${ }^{(1)}$}

\author{
Liovando Marciano da Costa ${ }^{(2)}$, Jairo Tronto ${ }^{(3)}$, Vera Regina \\ Leopoldo Constantino $^{(4)}$, Marilane Kalyetta Almeida Fonseca ${ }^{(5)}$, \\ Alessandra Pacobahyba Oliveira ${ }^{(6)} \&$ Marcelo Rocha da Costa ${ }^{(5)}$
}

\begin{abstract}
SUMMARY
The objective of this study was to extract and concentrate calcium oxalate (CaOx) crystals from plant leaves that form the above mentioned crystals. The chemical and physical studies of $\mathrm{CaOx}$ from plant to be performed depend on an adequate amount of the crystals. The plant used in this study was croton (Codiaeum variegatum). The leaves were ground in a heavy duty blender and sieved through a $0.20 \mathrm{~mm}$ sieve. The suspension obtained was suspended in distilled water. The crystals were concentrated at the bottom of a test tube. The supernatant must be washed until it is free of plant pigments and other organic substances. Biogenic $\mathrm{CaOx}$ crystals have well-defined and sharp peaks, indicating very high crystallinity. Moreover, the $\mathrm{CaOx}$ crystals were not damaged during the extraction procedure, as can be seen on the scanning electron microscope images. The porposed method can be considered efficient to extract and concentrate biogenic calcium oxalate.
\end{abstract}

Index terms: biogenic calcium oxalate, biomineral, extraction of calcium oxalate.

\section{RESUMO: EXTRAÇÃO E CONCENTRAÇÃO DE OXALATO DE CÁLCIO BIOGÊEICO DE FOLHAS DE PLANTAS}

Oobjetivo deste estudo foi extrair e concentrar cristais de oxalato de cálcio (CaOx) a partir de folhas de plantas que formam os cristais mencionados. Os estudos químicos e físicos de $\mathrm{CaOx}$ de plantas a serem realizados demandam uma massa adequada dos cristais. A planta usada neste estudo foi o cróton (Codiaeum variegatum). As folhas foram trituradas por um

\footnotetext{
${ }^{(1)}$ Recebido para publicação em junho de 2008 e aprovado em abril de 2009.

(2) Professor do Departamento de Solos, Universidade Federal de Viçosa - UFV. Av. PH Rolfs s/n, CEP 36570-000 Viçosa (MG). Bolsista do CNPq. E-mail: liovandomc@yahoo.com.br

(3) Universidade Federal de Viçosa, Campus de Rio Paranaíba. Rod BR 354, km 310, CEP 38810-000 Rio Paranaíba (MG). E-mail: jairotronto@gmail.com

(4) Instituto de Química, Departamento de Química Fundamental, Universidade de São Paulo - USP. Av. Lineu Prestes 748 , Bl. 2T, Butantã, CEP 05508-000 São Paulo (SP). E-mail: veraconst@gmail.com

(5) Medical Doctor. E-mails: marcelorochadacosta@yahoo.com.br

(6) Undergraduate student, UFV. E-mail: alessandra@mudhouse.co.nz
} 


\begin{abstract}
liquidificador industrial e peneiradas em peneira de $0,20 \mathrm{~mm}$. Ao suco obtido foi adicionada água destilada. Os cristais foram concentrados no fundo da proveta. É necessário manter a lavagem dos cristais até que o sobrenadante fique livre de pigmentos de plantas e outras substâncias orgânicas. Os cristais de CaOx apresentaram picos bem formados e estreitos, indicando que sua cristalinidade é muito alta; além disso, esses cristais não foram danificados durante o procedimento de extração, o que pode ser visto observando-se as fotos obtidas pelo microscópio eletrônico de varredura. O método apresentado pode ser considerado eficiente para extrair e concentrar cristais de oxalato de cálcio biogênico.
\end{abstract}

Termos de indexação: oxalato de cálcio biogênico, biomineral , extração de oxalato de cálcio.

\section{INTRODUCTION}

The presence of significant amounts of calcium oxalate $(\mathrm{CaOx})$ crystals in families of superior plants demonstrates that the formation of calcium oxalate crystals is an important physiologic process in many plant species. Furthermore, a better comprehension of the crystalline forms of $\mathrm{CaOx}$ in plants, which are added to the soil through plant residues will be needed to understand the calcium cycle in the plant and soil system. The stability of $\mathrm{CaOx}$ in different soils should also be studied in the future.

$\mathrm{CaOx}$ crystals in plants are formed from endogenously synthesized oxalic acid and calcium from the soil solution in contact with plant roots. To form a crystal, the soil solution should be in an unstable supersaturated state. However, chemical agents can act as heterogeneous nucleators reducing the metastable limit and promoting crystal formation (Franceschi \& Nakata, 2005).

The range of morphologies of the $\mathrm{CaOx}$ compounds is very large and can include block-like rhombohedral or prismatic crystals, found as single or multiple crystals per cell, bundles of needle-shaped (acicular) raphide crystals, masses of small angular crystals referred to as crystal sand, and multifaceted conglomerate crystals called druses (often single but also multiple per cell). The hydration state of the crystal, the calcium/oxalate ratio, the presence of nucleating or pollutant substances (Guo et al., 2002; Ouyang et al., 2003; Ryall et al., 2000; Touryan et al., 2004) and the existence of specialized cellular structures can play a decisive role in the morphology of CaOx crystals (Arnott \& Pautard, 1970; Horner \& Wagner, 1980; Jauregui-Zuniga et al., 2003; Nakata, 2003; Webb, 1999).

The production of crystals in plants is a physiologic process. $\mathrm{CaOx}$ is also found in animals but, unlike in plants, it is usually associated to a pathological condition of animals, to renal lithiase. CaOx can also occur as a structural element or as potential defense in other species. In spite of the lack of evidence to base some functional properties of $\mathrm{CaOx}$, the participation of $\mathrm{CaOx}$ in the regulation of intra and extra-cellular calcium, in plant protection and metal detoxification is quite evident.
Within the plant, the format, size, location as well as the total number of crystals are important to prevent the herbivore activity of large animals and insects. The ingestion of soluble oxalate can interfere in the calcium metabolism and it could precipate as $\mathrm{CaOx}$ in the tissue or organs of the herbivores. The ingestion of plants with high rates of oxalic acid for animals in the pastures can cause serious toxic consequences, such as a renal inadequacy.

In human health, the presence of high oxalate concentrations in vegetable foods and/or the occurrence of a genetic predisposition to renal problems can result in a similar intoxication effect. Oxalate in vegetable foods can have a negative effect on the human body, acting as anti-nutrient, or as a toxin, resulting in the formation of $\mathrm{CaOx}$ stones in the kidney (Stamatelou et al., 2003).

Recent studies have indicated that dietary oxalate contributes to an increased excretion of urinary oxalate. Spinach, peppers, rhubarb, nuts, plantains, and dry beans are examples of oxalate-containing plant foods (Franceschi \& Nakata, 2005).

Recently, there has been a growing interest to understand the formation mechanisms and use of these materials in plants. This study described a method of extraction and concentration of calcium oxalate from plant leaves. The objective of this study was to develop a laboratory method to extract and concentrate biogenic calcium oxalate crystals for chemical and physical studies.

\section{MATERIAL AND METHODS}

A plant species that contains calcium oxalate crystals must be selected. The species used in this study was croton (Codiaeum variegatum). After the selection of the plant species, leaves must be picked in a sufficient amount to obtain calcium oxalate crystals for further physical and chemical analysis.

The leaves were washed with distilled water to remove impurities and at last rinsed in deionized water. The leaves were cut in smaller pieces, filled in a heavy-duty blender, and covered with deionized water to $5 \mathrm{~cm}$ above the plant material. The device must 
work until obtaining a greenish juice of the leaves. The liquefied material was sifted through a $0.20 \mathrm{~mm}$ sieve. A sample of 20 crystals extracted from croton leaves was measured and the values varied from 0.004 to $0.018 \mathrm{~mm}$. The $0.20 \mathrm{~mm}$ sieve was adequate to separate the fibrous leaf material from the plant juice and the $\mathrm{CaOx}$ crystals. The plant material retained in the sieve was ground again in the blender. The procedure must be repeated until the plant juice becomes totally clear.

The volume of extracted plant juice was placed in $1000 \mathrm{~mL}$ test tubes for sedimentation of the calcium oxalate crystals and plant material. The sedimentation process must be repeated until the supernatant is light-colored and free of chlorophyll, pigments as well as other organic water-soluble compounds. The solid material containing the calcium oxalate crystals and other not water-soluble impurities were at the bottom of the test tube. The supernatant was removed by draining off.

In the end of the extraction, the formed sediment can be transferred to smaller test tubes $(100 \mathrm{~mL})$ to concentrate the extracted material. After concentrating the suspension, the solid product was dried at $60^{\circ} \mathrm{C}$.

Hydrogen peroxide (30 \%) was added to the dry material and the suspension formed was left to rest for $24 \mathrm{~h}$ to remove the organic impurities. Hydrogen peroxide was added until it covering the solid material by $2 \mathrm{~cm}$. After $24 \mathrm{~h}$ reacting with the organic substances the $\mathrm{CaOx}$ crystals were free of impurities. The optical microscope was used to observe the purity of the calcium oxalate crystals. The procedure with hydrogen peroxide can be repeated in case of any remaining impurities. The resulting solid material was washed with deionized water to remove impurities and dried at $60^{\circ} \mathrm{C}$.

The powder X-ray diffraction patterns (PXRD) for the materials were obtained using a Rigaku diffractometer model Miniflex with a graphite monochromator selecting the $\mathrm{CuK} \alpha$ line. A step of $0.02 \%$ s was used in the angular domain 10-70 .

The morphology of the calcium oxalate crystals was analyzed by scanning electron microscopy (SEM) in a Zeiss DSM 960 - Digital Scanning Microscope.

\section{RESULTS AND DISCUSSION}

The PXRD patterns of synthetic (Aldrich $\left.{ }^{\circledR}\right)$ and biogenic calcium oxalate crystals are shown in figure 1; both are quite similar. Results indicate the presence of biogenic $\mathrm{CaOx}$ with a high degree of crystallinity. The main peaks of the diffractograms were very sharp. This feature is a good indicator of the crystallinity of the calcium oxalate.

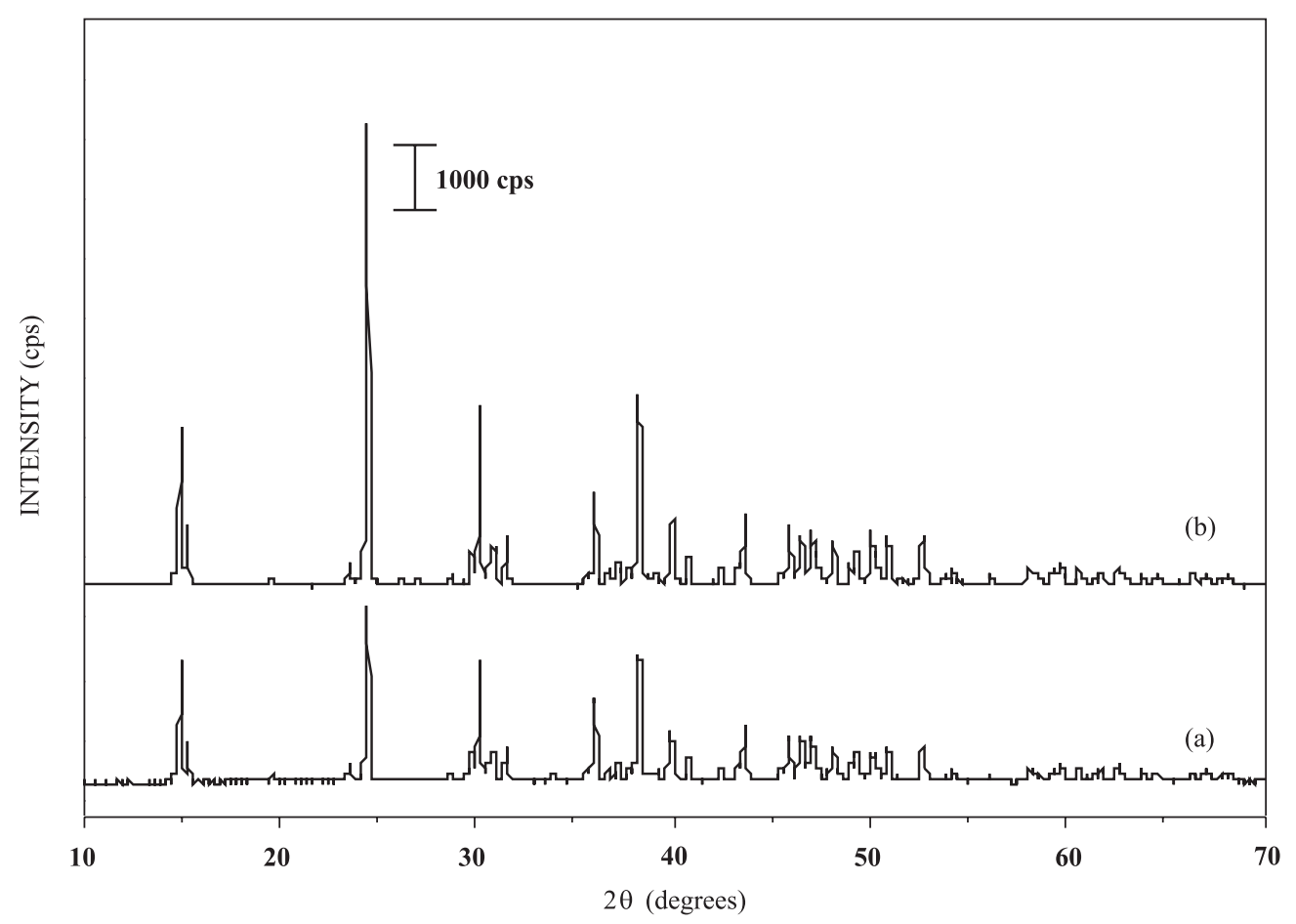

Figure 1. (a) Powder X-ray Diffraction Patterns of (a) synthetic calcium oxalate and (b) biogenic calcium oxalate. 
The SEM images of synthetic and biogenic $\mathrm{CaOx}$ are shown in figure 2 . In relation to synthetic $\mathrm{CaOx}$, the crystals of the biogenic material are larger with clearly defined forms, similarly to a carnation flower. The SEM images show morphological differences between synthetic and biogenic crystals. The biogenic crystals were not damaged but preserved during the extraction and concentration procedure. These results confirm the efficiency of the extraction and concentration process described here.

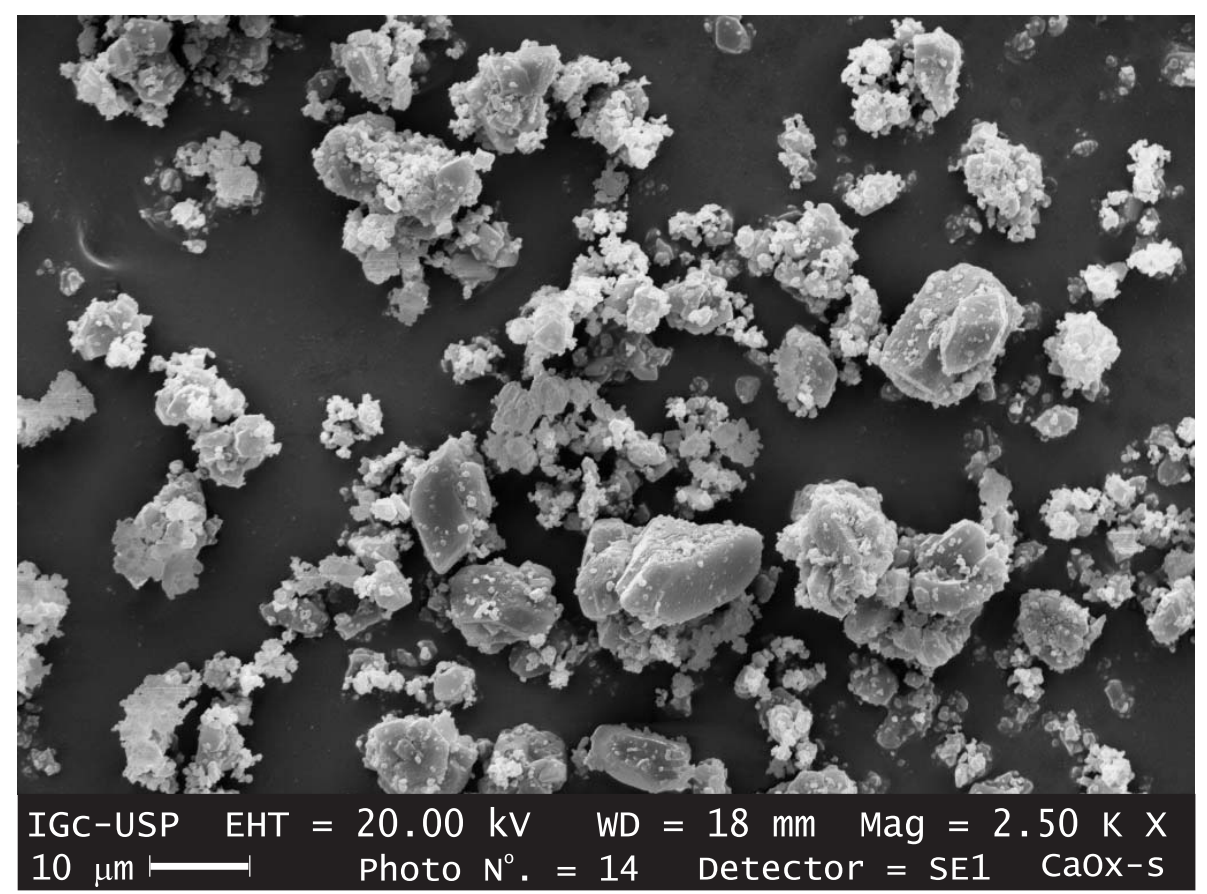

(a)

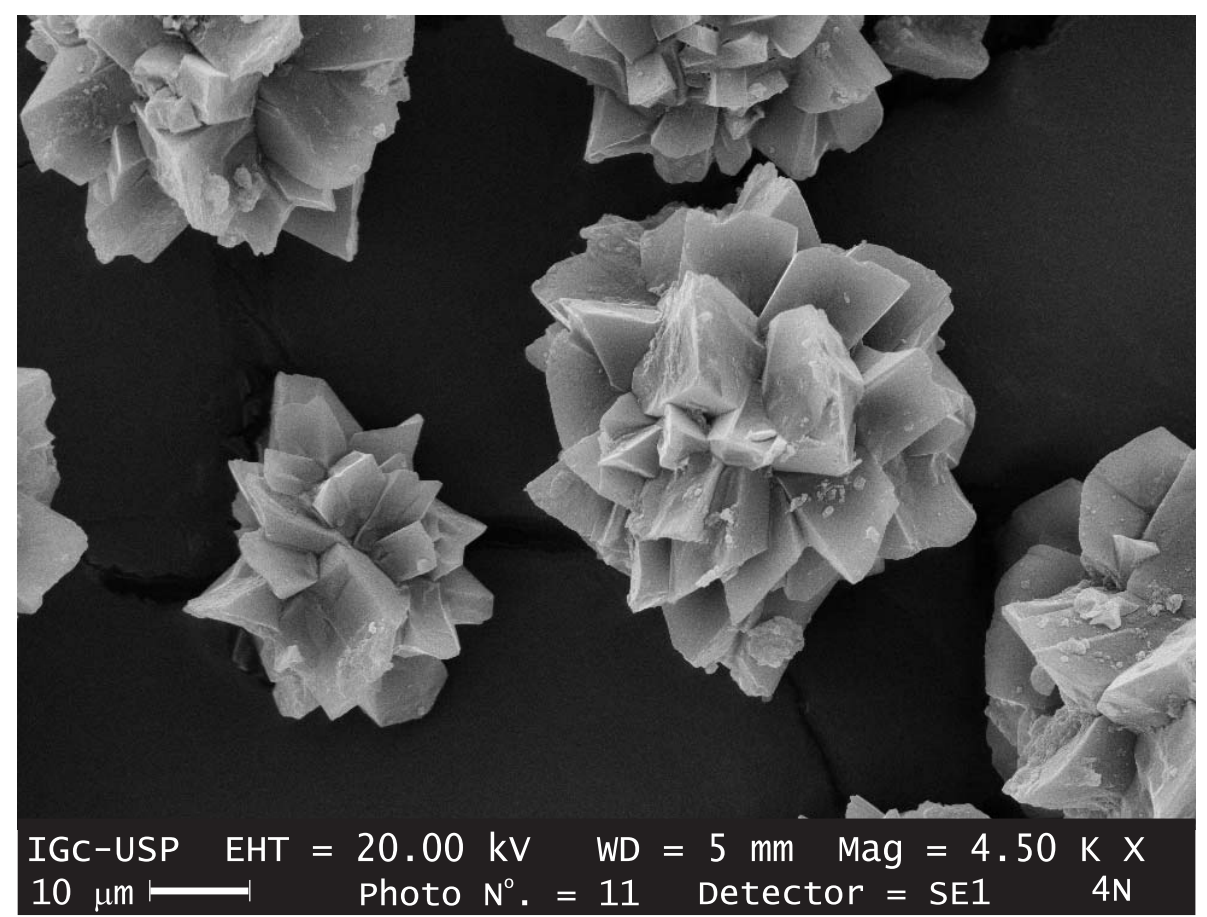

(b)

Figure 2. Scanning Electron Microscopy of (a) synthetic calcium oxalate; (b) biogenic calcium oxalate. 


\section{CONCLUSIONS}

1. The degree of crystallinity of biogenic calcium oxalate is high.

2. The crystals are not damaged during the laboratory procedure.

\section{LITERATURE CITED}

ARNOTT, H.J. \& PAUTARD, F.G.E. Calcification in plants. In SCHRAER, H. ed. Biological calcification: Cellular and molecular aspects. New York, Appleton-Century-Crofts, 1970. p.375-446.

FRANCESCHI, V.R. \& NAKATA, P.A. Calcium oxalate in plants: Formation and function. Ann. Rev. Plant. Biol., 56:41-71, 2005.

GUO, S.W.; WARD, M.D. \& WESSON, J.A. Direct visualization of calcium oxalate monohydrate crystallization and dissolution with atomic force microscopy and the role of polymeric additives. Langmuir, 18:4284-4291, 2002.

HORNER, H.T. \& WAGNER, B.L. The association of druse crystals with the developing stomium of Capsicum annuum (Solanaceae) anthers. Am. J. Bot., 67:1347-60, 1980.
JAUREGUI-ZUNIGA， D.; REYES-GRAJEDA， J.P.; SEPULVEDA-SANCHEZ, J.D.; WHITAKER, J.R. \& MORENO, A. Crystallochemical characterization of calcium oxalate crystals isolated from seed coats of Phaseolus vulgaris and leaves of Vitis vinifera. J. Plant Physiol., 160:239-245, 2003.

NAKATA, P.A. Advances in our understanding of calcium oxalates generated as biominerals in cacti. Plant Sci., 164:901-909, 2003.

OUYANG, J.M.; DUAN, L. \& TIEKE, B. Effects of carboxylic acids on the crystal growth of calcium oxalate nanoparticles in lecithin-water liposome systems. Langmuir, 19:8980-8985, 2003.

RYALL, R.L.; FLEMING, D.E.; GROVER, P.K.; CHAUVET, M.; DEAN, C.J. \& MARSHALL, V.R. The hole truth: Intracrystalline proteins and calcium oxalate kidney stones. Molec. Urol., 4:391-402, 2000.

STAMATELOU, K.K.; FRANCIS, M.E.; JONES, C.A.; NYBERG JR., L.M. \& CURHAN, G.C. Time trends in reported prevalence of kidney stones in the United States: 19761994. Kidney Inter., 63:1817-1823, 2003.

TOURYAN, L.A.; LOCHHEAD, M.J.; MARQUARDT, B.J. \& VOGEL, V. Sequential switch of biomineral crystal morphology using trivalent ions. Nat. Mater., 3:239-243, 2004.

WEBB, M.A. Cell-mediated crystallization of calcium oxalate in plants. Plant Cell, 11:751-761, 1999. 
